\title{
Physical and Mechanical Characterization of Astronium Lecointei and Manilkara Huberi Branch Wood
}

Anselmo Junior Corrêa Araujo ${ }^{1}$ (D) 0000-0002-8649-5299

Bruno Monteiro Balboni ${ }^{1}$ (i) 0000-0003-1617-5254

Victor Moutinho $^{1}$ (ㅇ 0000-0001-7770-3087

\begin{abstract}
Forest harvest residues are usable; however, studies on their quality are incipient. Thus, our study sought to perform physico-mechanical characterization of wood from the branches of Astronium lecointei and Manilkara huberi, as well as to compare its properties with trunk material found in the literature. The material was collected in the Tapajós National Forest (Flona - Tapajós) and cut for the trials performed at the Universidade Federal do Oeste do Pará (Ufopa). Descriptive statistics were used for data analysis and the averages were compared with values found in the literature for the trunk of the studied species and other commercial wood of the region. The physical properties of Astronium lecointei and Manilkara huberi showed approximate averages to those of trunk, while the mechanical properties presented lower averages. Therefore, regarding the mechanical properties, the residues may be substituents for the trunks of other species for having similar properties.
\end{abstract}

Keywords: residues, alternative utilization, technological properties.

\section{INTRODUCTION AND OBJECTIVES}

Branches, flat roots (sapopemas) and trunk remains, among others, are understood as residues of forest harvesting. Normative Instruction number 5 of December 11, 2006 of the Brazilian Ministry of the Environment (Brasil, 2006) legalizes and regulates the use of this material. However, the legislation clarifies the obligatory nature of studies that subsidize this activity, especially regarding the dendrometry.

In this sense, a study conducted by Silva-Ribeiro (2016) in the state of Pará shows that about $0.4 \mathrm{~m}^{3}$ for each cubic meter of wood harvested in logs are left in the forest in the form of residues (twigs $>20 \mathrm{~cm}$ in diameter). Studies such as that by Shen et al. (2009) and Nati et al. (2017) show the possibility of using this material as an energy source; however, other uses can be evaluated according to their dimensions. Despite the clear relevance of this material in native forests, initiatives for its use are still incipient.

The lack of industrial interest in this raw material is mainly because of the unfamiliarity with this material and its potentialities, which makes it difficult to enter the market. Thus, it is of scientific scope to investigate the properties of these residues for better visibility of their applicability. In this context, physical and mechanical properties present themselves as important indicators to evaluate woods of different origins, ages, and treatments (Pollet et al., 2017).

Regarding the wood from branches, it is also questioned if the properties are discrepant when compared with the trunk; thus, in addition to performing the physical and mechanical characterization of the wood from branches of Astronium lecointei and Manilkara huberi, our study also sought to compare the results with trunk data found in the literature.

\section{MATERIALS AND METHODS}

\subsection{Description of species collection and selection area}

The material used in our study was from the Tapajós National Forest, located at coordinates $2^{\circ} 45^{\prime}$ and $4^{\circ} 10^{\prime} \mathrm{S}$ and $54^{\circ} 45^{\prime}$ and $55^{\circ} 30^{\prime} \mathrm{W}$ at $\mathrm{Km} 83$ of the Santarém-CuiabáBR-163 Highway, coming from an area of forest management activity certified by the Forest Stewardship Council (FSC). The species were selected according to the highest volume

${ }^{1}$ Universidade Federal do Oeste do Pará (Ufopa), Santarém, PA, Brasil 
marketed between 2009 and 2013 (SEMAS, 2015). Thus, the species Astronium lecointei Ducke (muiracatiara) and Manilkara huberi (Ducke) Chevalier (maçaranduba) met this criterion.

\subsection{Collection of material and taxonomic identification}

The tree material was collected from three individuals of each species during the forest harvesting activity of the Mixed Cooperative of the Tapajós National Forest (Coonflona). The trees were duly identified according to their botanical characters, and then the material from the branches was sectioned from the first bifurcation and transported to a portable mill (Lucas Mill), where $12 \times 12 \mathrm{~cm}$ thick and wide pieces were cut with a minimum length of 2 meters, as shown in Figure 1. The pieces were later transported to a sawmill, where the test specimens were prepared for the tests, and the material was subsequently transported to the Wood Technology Laboratory (LTM), of the Universidade Federal do Oeste do Pará (Ufopa), for acclimatization and testing.

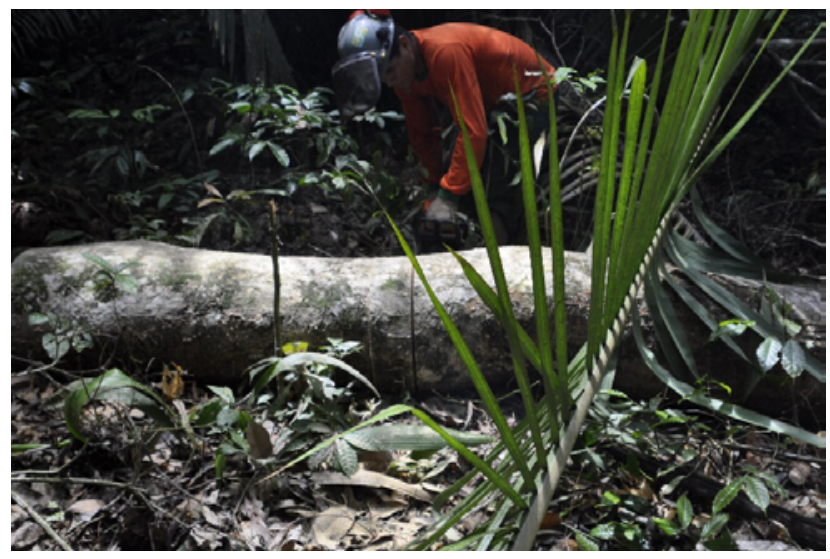

Figure 1. Branch material during the sectioning process.

\subsection{Physical and mechanical characterization of wood}

The physical and mechanical properties of the wood were characterized using the procedures provided in NBR7190 (ABNT, 1997). The physical variables determined were: longitudinal $(\beta \mathrm{l})$, radial $(\beta \mathrm{r})$, tangential $(\beta \mathrm{t})$ and volumetric $(\beta \mathrm{v})$ contractions, anisotropy coefficient $(\mathrm{AC})$, basic density $\left(\rho_{\mathrm{b}}\right)$ and bulk density at $12 \%$ moisture content $\left(\rho_{12 \%}\right)$. The mechanical properties evaluated were: hardness $\left(f_{H}\right)$ proposed by Janka, parallel compression strength $\left(\mathrm{f}_{\mathrm{c} 0}\right)$, and modulus of rupture $\left(\mathrm{f}_{\mathrm{M}}\right)$ and elasticity $\left(\mathrm{E}_{\mathrm{M} 0}\right)$ in static bending strength tests, parallel fiber compression and hardness, performed in a DL $300 \mathrm{kN}$ universal testing machine (EMIC brand).

\subsection{Data analysis}

Data were subjected to descriptive statistics, obtaining means, standard deviation and coefficient of variation (\%). These analyses were performed using Gretl statistical software (Baiocchi \& Ditaso, 2003). Simultaneously, we consulted studies in the literature that contained physical and mechanical characterization of the trunk wood of Astronium lecointei and Manilkara huberi and also of other commercial species to compare the results obtained. The characteristic values of the parallel compression strength $\left(f_{c 0}\right)$ were estimated to fit the branch wood of both species to the strength classes provided for in NBR-7190 (ABNT, 1997). The values found were transformed into a $12 \%$ moisture when necessary, also in accordance with the NBR-7190 (ABNT, 1997).

\section{RESULTS AND DISCUSSION}

\subsection{Physical properties}

The physical parameters of the Astronium lecointei and Manilkara huberi wood are shown in Table 1.

The wood in which higher density values were observed also found higher levels of contraction in all axes and in their volume, except for the value observed in the longitudinal axis. As observed, longitudinal contraction values were expected to be lower than $1 \%$. The high coefficients of variation are directly related to the precision of the equipment used in the measurement, along with the fact that the differences between the longitudinal dimensions in the saturated and anhydrous states are minimal.

The study by Vidaurre et al. (2018) evaluated the physical properties of Schizolobium amazonicum (a lowdensity wood), and they concluded that the contraction of the wood was low. In this sense, several articles have shown the direct positive correlation between the wood density and contraction levels. The results of our study follow the same assumption. It is also noted that the contraction values in the tangential axis were higher than the contraction values in the radial axis. Ribeiro et al. (2014) also found superior tangential contraction values to radial values and suggests that such a phenomenon can occur due to the organization and characteristics of the wood elements. 
Table 1. Physical properties of wood from branches of Astronium lecointei and Manilkara huberi.

\begin{tabular}{|c|c|c|c|c|c|c|c|}
\hline \multirow{2}{*}{ Variables } & \multirow{2}{*}{$\rho_{12 \%}\left(\mathrm{~g} \cdot \mathrm{cm}^{-3}\right)$} & \multirow{2}{*}{$\rho_{\mathrm{b}}\left(\mathrm{g} \cdot \mathrm{cm}^{-3}\right)$} & \multicolumn{4}{|c|}{ Maximum contraction (\%) } & \multirow{2}{*}{ AC } \\
\hline & & & $\beta 1$ & $\beta \mathbf{t}$ & $\beta \mathbf{r}$ & $\beta \mathbf{v}$ & \\
\hline \multicolumn{8}{|l|}{ Astronium lecointei } \\
\hline Mean & 0.809 & 0.690 & 0.831 & 6.844 & 4.367 & 10.399 & 1.587 \\
\hline Standard deviation & 0.067 & 0.056 & 0.218 & 0.845 & 0.563 & 1.721 & 0.245 \\
\hline CV (\%) & 8.24 & 8.12 & 26.28 & 12.36 & 12.89 & 16.56 & 15.45 \\
\hline \multicolumn{8}{|l|}{ Manilkara huberi } \\
\hline Mean & 1.093 & 0.893 & 0.523 & 9.126 & 7.708 & 17.612 & 1.196 \\
\hline Standard deviation & 0.027 & 0.018 & 0.215 & 0.873 & 0.897 & 1.946 & 0.154 \\
\hline CV (\%) & 2.52 & 2.06 & 41.35 & 9.57 & 11.64 & 11.05 & 12.89 \\
\hline
\end{tabular}

$\rho_{12 \%}$ : bulk density at $12 \%$ moisture; $\rho_{\mathrm{b}}$ : basic density; $\beta \mathrm{l}$ : swelling; $\beta$ t: shrinking; $\beta \mathrm{r}$ : radial contraction; $\beta \mathrm{v}$ : volumetric contraction; AC: anisotropy coefficient; CV: coefficient of variation.

The contraction values referring to the tangential and radial axes were considered the most important ones, since they indicate the wood dimensional stability (Oliveira et al., 2010). The disproportion between these variables, called "the anisotropy coefficient," closer to 1 indicates the wood is more stable. Therefore, the wood of Manilkara huberi showed greater dimensional stability, since its anisotropic coefficient is 1.196, when compared with the wood of Astronium lecointei, which showed a higher coefficient, 1.587. Regarding this coefficient in native woods from Amazonia, Jesus et al. (2016) reported the occurrence of greater anisotropy to the greater specific mass; however, Almeida et al. (2017) do not recommend density as a good indicator of the dimensional stability of Amazonian tropical woods.

Longui et al. (2014) found bulk density values of approximately $0.92 \mathrm{~g} . \mathrm{cm}^{-3}$ and volumetric contraction of $10 \%$ when evaluating the physical properties of the trunks from Astronium lecointei. When comparing these results with those of branches, it is observed that the density is slightly lower, but the volumetric contraction shows a similar value. Baar et al. (2015) found a basic density of $0.84 \mathrm{~g} . \mathrm{cm}^{-3}$ for Astronium graveolens, which is higher than that found for the branches.

For Manilkara huberi, Silveira et al. (2013) and Carneiro et al. (2008) found basic density of $0.878{\mathrm{~g} . \mathrm{cm}^{-3}}^{-3}$ and $0.89 \mathrm{~g}$. $\mathrm{cm}^{-3}$, respectively, while Medeiros Neto et al. (2016) found an apparent density of $1.06 \mathrm{~g} . \mathrm{cm}^{-3}$; these values can be considered close to those for the branches. However, for Manilkara longifolia, Gonçalves et al. (2013) found a basic density of 0.94 g.cm ${ }^{-3}$.

Table 2 shows the mean values of the physical properties of Astronium lecointei and Manilkara huberi wood with values found in the literature for the trunk wood of these same species and other commercial species.

Table 2. Comparison of physical properties of wood from branches of Astronium lecointei and Manilkara huberi with physical properties of the trunk of the same species and other commercial woods.

\begin{tabular}{|c|c|c|c|c|c|}
\hline \multirow{2}{*}{ Species } & \multirow{2}{*}{$\rho_{12 \%}\left(\right.$ g. $\left.\mathrm{cm}^{-3}\right)$} & \multicolumn{3}{|c|}{ Maximum contraction (\%) } & \multirow{2}{*}{ A.C. } \\
\hline & & $\beta \mathbf{t}$ & $\beta \mathbf{r}$ & $\beta \mathbf{v}$ & \\
\hline Astronium lecointei- branch $^{1}$ & 0.690 & 6.844 & 4.367 & 10.399 & 1.587 \\
\hline Astronium lecointei- trunk ${ }^{2}$ & 0.75 & 7.20 & 4.10 & 11.00 & 1.70 \\
\hline Astronium lecointei- trunk $\mathrm{k}^{3}$ & 0.79 & 7.60 & 4.60 & 11.90 & 1.65 \\
\hline Goupia glabra - trunk ${ }^{3}$ & 0.71 & 7.80 & 4.50 & 12.30 & 1.77 \\
\hline Tachigali myrmecophila - trunk ${ }^{3}$ & 0.60 & 7.30 & 4.30 & 11.60 & 1.75 \\
\hline Manilkara huberi-branch ${ }^{1}$ & 0.893 & 9.126 & 7.708 & 17.612 & 1.196 \\
\hline Manilkara huberi - trunk ${ }^{2}$ & 0.93 & 9.40 & 6.80 & 16.00 & 1.40 \\
\hline Manilkara huberi - trunk ${ }^{3}$ & 0.87 & 9.31 & 7.10 & 16.38 & 1.31 \\
\hline Lecythis poiteaui- trunk $^{3}$ & 0.86 & 12.80 & 6.80 & 19.60 & 1.90 \\
\hline Bowdichia nitida - trunk ${ }^{3}$ & 0.80 & 8.60 & 6.00 & 14.60 & 1.43 \\
\hline
\end{tabular}

${ }^{1}$ Result obtained in our study; ${ }^{2}$ IBDF (1983); ${ }^{3}$ Andrade (2015). 
The physical properties of the Astronium lecointei branches show great similarities to the trunk wood of this species originating from Grande Carajás, PA, and Monte Dourado, PA. They are also close to physical properties of trunk wood of other commercial species of interest such as Goupia glabra (cupiúba) and Tachigali myrmecophila (tachi-preto).

Regarding Manilkara huberi, the branch wood did not show as much discrepancies in its physical properties when compared with the trunk wood from the same species, similar to what was observed in Astronium lecointei. Likewise, they can be grouped to the characteristics of the trunk of species such as Lecythis poiteaui (jarana-amarela) and Bowdichia nitida (sucupira-preta).

Therefore, regarding its physical properties, Astronium lecointei wood and Manilkara huberi branches show slightly different characteristics from the trunk wood such as the slightly lower density of the branches of both species. Small variations are also observed regarding shrinkability. It is also observed that the anisotropy coefficient of the branches is lower when compared with the trunk wood, having, therefore, greater dimensional stability.

\subsection{Mechanical properties}

The mechanical properties of the Astronium lecointei and Manilkara huberi branches are shown in Table 3.

The data confirmed the tendency of the higher-density woods to show the greatest strength. Longui et al. (2014) found a $\mathrm{f}_{\mathrm{c} 0}$ parallel compression value for the Astronium lecointei trunk fibers of approximately $145 \mathrm{MPa}$, that is, the branches only represent $35 \%$ of this value. This same author also found $\mathrm{f}_{\mathrm{M}}$ values near $100 \mathrm{MPa}$ in static bending for this species, that is, the branch shows values more than $40 \%$ lower. Baar et al. (2015) found $f_{c 0}$ value of parallel compression to the fibers of $138.05 \mathrm{MPa}$ and $\mathrm{E}_{\mathrm{M} 0}$ in the static bending of 14.29 GPa for Astronium graveolens, which, despite being another species of the same genus, also showed superior strength to that of the branches.

For Manilkara huberi, Medeiros Neto et al. (2016) found $\mathrm{E}_{\mathrm{M} 0}$ and $\mathrm{f}_{\mathrm{M}}$ values in the static bending of $16.39 \mathrm{GPa}$ and 186.31 MPa, being much higher values than those of the branches.

Table 4 shows the averages of the mechanical properties studied for Astronium lecointei and Manilkara huberi wood with values obtained in the literature for the trunks of these same species and other commercial woods.

Unlike the physical properties, the mechanical properties of the branches were considerably lower than those of the trunk, when considering Astronium lecointei and Manilkara huberi. For Astronium lecointei, the greatest differences were observed in the parallel fiber compression tests, in which the trunk strength ranged between $82.40 \mathrm{MPa}$ and 91.75 MPa, when compared with 52.07 MPa of the branch. Differences in $f_{M}$ in this species are also highlighted for the trunk, ranging between 102.22 $\mathrm{MPa}$ and $158.79 \mathrm{MPa}$, while in the branch it was only $57.63 \mathrm{MPa}$. However, there are commercial species with mechanical properties similar to those of Astronium lecointei such as Caryocar villosum (pequiá) and Erisma uncinatum (cedrinho). This allows us to infer that the Astronium lecointei branches can have the same applications as these species when considered the mechanical properties.

Table 3. Mechanical properties of wood from branches of Astronium lecointei and Manilkara huberi.

\begin{tabular}{|c|c|c|c|c|c|c|}
\hline \multirow{2}{*}{ Variables } & \multirow{2}{*}{$\begin{array}{c}\text { Compression parallel } \\
\text { to fibers } \\
\mathrm{f}_{\mathrm{c} 0}(\mathrm{MPa})\end{array}$} & \multicolumn{3}{|c|}{ Janka $\mathrm{f}_{\mathrm{H}}(\mathrm{KN})$} & \multicolumn{2}{|c|}{ Static bending } \\
\hline & & Trans. & Tang & Rad. & $\mathrm{E}_{\mathrm{M} 0}(\mathrm{GPa})$ & $\mathrm{f}_{\mathrm{M}}(\mathrm{MPa})$ \\
\hline \multicolumn{7}{|l|}{ Astronium lecointei } \\
\hline Mean & 52.069 & 6.237 & 6.112 & 6.616 & 8.106 & 57.631 \\
\hline Standard deviation & 8.268 & 1.137 & 1.580 & 1.902 & 2.504 & 22.308 \\
\hline $\mathrm{CV}(\%)$ & 15.88 & 18.23 & 25.86 & 28.75 & 30.89 & 38.71 \\
\hline \multicolumn{7}{|l|}{ Manilkara huberi } \\
\hline Mean & 71.997 & 6.112 & 14.490 & 14.574 & 13.777 & 100.960 \\
\hline Standard deviation & 3.084 & 1.580 & 0.995 & 0.849 & 1.379 & 16.793 \\
\hline $\mathrm{CV}(\%)$ & 4.28 & 25.86 & 6.87 & 5.82 & 10.01 & 16.63 \\
\hline
\end{tabular}

$\mathrm{fc}_{0}$ : modulus of rupture of the parallel compression to the fibers; $\mathrm{f}_{\mathrm{H}}$ : hardness; $\mathrm{E}_{\mathrm{M} 0}$ : bending; $\mathrm{CV}$ : coefficient of variation. 
Table 4. Mechanical properties of wood from branches of Astronium lecointei and Manilkara huberi and from the trunks of the same species and other commercial woods.

\begin{tabular}{|c|c|c|c|c|c|}
\hline \multirow{2}{*}{ Species } & \multirow{2}{*}{$\mathrm{f}_{\mathrm{c} 0}(\mathrm{MPa})$} & \multicolumn{3}{|c|}{ Janka $f_{H}(K N)$} & \multirow[t]{2}{*}{$\mathrm{E}_{\mathrm{M} 0}(\mathrm{GPa})$} \\
\hline & & Trans. & Tang & Rad & \\
\hline Astronium lecointei- branch $^{1}$ & 52.069 & 6.237 & 6.112 & 6.616 & 8.106 \\
\hline Astronium lecointei- trunk $^{2}$ & 91.75 & 9.40 & & 8.38 & 13.73 \\
\hline Astronium lecointei- trunk $^{3}$ & 82.40 & 8.66 & & 7.69 & 12.95 \\
\hline Astronium lecointei- trunk $^{5}$ & 82.40 & 9.59 & & 8.74 & 15.01 \\
\hline Caryocar villosum - trunk $^{3}$ & 50.70 & 8.16 & & 7.67 & 10.98 \\
\hline Erisma uncinatum - trunk $^{3}$ & 49.42 & 5.15 & & 6.30 & \\
\hline Manilkara huberi - branch ${ }^{1}$ & 71.997 & 6.112 & 14.490 & 14.574 & 13.777 \\
\hline Manilkara huberi - trunk ${ }^{2}$ & 109.92 & 17.40 & & 12.30 & 29.97 \\
\hline Manilkara huberi - trunk ${ }^{3}$ & 108.79 & 13.60 & & 14.90 & 17.07 \\
\hline Manilkara huberi - trunk ${ }^{4}$ & 82.9 & - & & - & - \\
\hline Mezilaurus itauba - trunk $^{3}$ & 70.60 & 13.76 & & 14.01 & 14.77 \\
\hline Manilkara bidentata - trunk $^{3}$ & 68.26 & 9.67 & & 9.63 & 13.32 \\
\hline
\end{tabular}

${ }^{1}$ Result obtained in our study; ${ }^{2}$ IBDF (1983); ${ }^{3}$ Andrade (2015); ${ }^{4}$ ABNT (1997). FM: maximum force; KN: kilo newton; MCS: maximum compressive strength; MOR: modulus of rupture; and MOE: modulus of elasticity.

A similar relationship was observed in Manilkara huberi, especially in the static bending tests, in which the highest trunk MOR and MOE values were 244.33 MPa and 27.97 GPa, respectively. The branches only showed $100.96 \mathrm{MPa}$ and 13.80 GPa for the same variables. On the other hand, in comparison with ABNT data (1997), the branch and the trunk of this species have similar compressive strength parallel to the fibers. Timber from species such as Mezilaurus itauba (itauba-amarela) and Manilkara bidentata (maparajuba) show broadly similar characteristics.

A possible explanation for the reduced strength from the trunk to the branch is the greater incidence of defects in this region of the tree like knots and irregular grains. Grazide et al. (2017) identified wood defects according to size and location such as nodes formed during their physiological development, which have a degrading influence on their mechanical properties. In their study, Zhou et al. (2018) explain that the discontinuity of the polymer such as an irregular grain has a negative effect on the mechanical properties. Although the tested pieces were free from such defects, the occurrence of these on the branches exerts influence on the whole woody tissue.

The characteristic value for the parallel compressive strength was 47.82 MPa for Astronium lecointei, and 73.37 MPa for Manilkara huberi, which places them in C40 and C60 classes, respectively, being the second largest and the highest strength class for angiosperm wood of NBR-7190 (ABNT, 1997). We think it is important to emphasize that the classes refer to wood free from defects such as knots, grain diversion, resin bags, among others, which constitute characteristics more easily found in branches than in trunks, and which should be considered when using this type of material.

Based on the aforementioned information, it can be inferred that the Astronium lecointei and Manilkara huberi branches cannot be used in the same way as the trunk, since they had considerably lower strength. Resizing beams and pillars made with branches to support the required load would be an alternative to this problem in structural applications. However, we believe it is necessary to first evaluate the amount of branch raw material available to meet the demand for resizing. Thus, branches of these species are suggested to be used in structures in situations in which stresses (compression and flexion) require less strength.

Another viable alternative is the use of this material in manufacturing furniture, which does not require great mechanical strength or parts of great magnitude. Moreover, the presence of defects can function as aesthetic appeal on specific occasions.

\section{CONCLUSIONS}

The physical characteristics of the wood from branches (forest harvest residues) in our study show slightly different 
averages in the analyzed variables from those of the trunk and of other Amazonian commercial species. However, their mechanical properties showed highly inferior averages when compared with the trunk values of the same species, but similar to properties of trunks of other species widely marketed in the region.

\section{ACKNOWLEDGEMENTS}

To the Universidade Federal do Oeste do Pará (Ufopa), for the funding given to conduct this study.

\section{SUBMISSION STATUS}

Received: 10 Apr. 2017

Accepted: 28 Sept. 2018

Associate editor: Edy Eime Baraúna

(D) 0000-0001-5239-9592

\section{CORRESPONDENCE TO \\ Anselmo Junior Corrêa Araujo}

Universidade Federal do Oeste do Pará (Ufopa), Rua Vera Paz, s/n, Unidade Tapajós, Bairro Salé, CEP 68035-110, Santarém, PA, Brasil e-mail: anselmojunior.stm@gmail.com

\section{REFERENCES}

Almeida TH, Almeida DH, Araújo VA, Silva SAM, Christoforo AL, Lahr FAR. Density as estimator of dimensional stability quantities of Brazilian tropical woods. BioResources 2017; 12(3): 6579-6590.

Andrade A. pisos de madeira: características de espécies brasileiras. Piracicaba: ANMP; 2015

Associação Brasileira de Normas Técnicas - ABNT. NBR-7190: projeto de estruturas de madeira. Rio de Janeiro; 1997.

Baar J, Tippner J, Rademacher P. Prediction of mechanical properties: modulus of rupture and modulus of elasticity of five tropical species by nondestructive methods. Maderas. Ciencia y Tecnología 2015; 17(2): 239-252. 10.4067/S0718221X2015005000023

Baiocchi G, Ditaso W. GRETL: econometric software for the GNU generation. Journal of Applied Econometrics 2003; 18: 105-110. $10.1002 /$ jae.704

Brasil. Instrução normativa $\mathrm{n}^{\circ}$ 5, de 11 de dezembro de 2006. Procedimentos técnicos para elaboração, apresentação, execução e avaliação técnica dos Planos de Manejo Florestal Sustentável - PMFS nas florestas primárias e suas formas de sucessão na Amazônia Legal. Diário Oficial da União, Brasília, DF (2006 Dec. 13); Sec. 1: 155.

Carneiro JS, Emmert L, Sternadt GH, Mendes JC, Almeida GF. Decay susceptibility of Amazon wood species from Brazil against white rot and brown rot decay fungi. Holzforschung 2008; 63(6): 767-772. 10.1515/HF.2009.119

Gonçalves F, Pinheiro DTC, Paes JB, Carvalho AG. Durabilidade natural de espécies florestais madeireiras ao ataque de cupim de madeira seca. Floresta e Ambiente 2013, 20(1): 110-116. 10.4322/ floram.2012.063
Grazide C, Coureau JL, Cointe A, Morel S. Mechanical performance curves for the strength grading of maritime pine. European Journal of Wood and Wood Products 2017; 76(3): 877-888. 10.1007/s00107017-1241-4

Instituto Brasileiro de Desenvolvimento Florestal - IBDF. Potencial madeireiro do Grande Carajás. Brasília: IBDF; 1983.

Jesus AG, Modes KS, Santos LMH, Bento AR, Gusmão M. Comportamento das madeiras de três espécies amazônicas submetidas à secagem ao ar. Nativa 2016; 4(1): 31-35. 10.14583/2318-7670.v04n01a07

Longui EL, Lima IL, Lombardi DR, Garcia JN, Alves ES. Woods with physical, mechanical and acoustic properties similar to those of Caesalpinia echinata have high potential as alternative woods for bow makers. Cerne 2014; 20(3): 369-376. $10.1590 / 01047760201420031345$

Medeiros Neto PNM, Paes JB, Segundinho PGA. Determinações dos módulos de elasticidade e ruptura de madeiras por técnicas não destrutivas e destrutivas. Scientia Forestalis 2016; 44(111): 683-690. 10.18671/scifor.v44n111.14

Nati C, Boschiero M, Picchi G, Mastrolonardo G, Kelderer M, Zerbe S. Energy performance of a new biomass harvester for recovery of orchard wood wastes as alternative to mulching. Renewable Energy 2017; 124(spec. ed.): 121-128. 10.1016/j. renene.2017.07.030

Oliveira JTS, Tomazello Filho M, Fiedler NC. Avaliação da retratibilidade da madeira de sete espécies de Eucalyptus. Revista Árvore 2010; 34(5): 929-936. 10.1590/S0100-67622010000500018

Pollet C, Henin JM, Hébert J, Jourez B. Effect of growth rate on the physical and mechanical properties of Douglas-fir in western Europe. Canadian Journal of Forest Research 2017; 47(8): 10561065. $10.1139 /$ cjfr-2016-0290

Ribeiro AO, Mendes RF, Mendes LM, Mori FA, Ziech RQS. Retratibilidade da madeira de Toona ciliata M. Roem proveniente de três municípios do sul de Minas Gerais. Cerne 2014; 20(3): 351-361. 10.1590/01047760201420031315

Secretaria de Estado de Meio Ambiente e Sustentabilidade SEMAS. Extração e movimentação de tora de madeiras nativas por município: relatórios anuais, 2009-2013. Belém: SEMAS; 2015.

Shen J, Wang XS, Garcia-Perez M, Mourant D, Rhodes MJ, Li CZ. Effects of particle size on the fast pyrolysis of oil mallee woody biomass. Fuel 2009; 88(10): 1810-1817. 10.1016/j.fuel.2009.05.001

Silva-Ribeiro RB, Gama JRV, Souza AL, Leite HG, Soares CPB, Silva GF. Métodos para estimar o volume de fustes e galhos na floresta nacional do Tapajós. Revista Árvore 2016; 40(1): 81-88. 10.1590/0100-67622016000100009

Silveira LHC, Rezende AV, Vale AT. Teor de umidade e densidade básica da madeira de nove espécies comerciais amazônicas. Acta Amazonica 2013; 43(2): 179-184. 10.1590/S004459672013000200007

Vidaurre GB, Vital BR, Oliveira AC, Oliveira JTS, Moulin JC, Silva JCM, Soranso DR. Physical and mechanical properties of juvenile Schizolobium amazonicum Wood. Revista Árvore 2018; 42(1): e420101. 10.1590/1806-90882018000100001

Zhou AP, Bian YL, Shen YR, Huang DS, Zhou MJ. Inelastic bending performances of laminated bamboo beams: experimental investigation and analytical study. BioResources 2018; 13(1): 131-146. 